\title{
Algunos apuntes sobre enfermedades y remedios de Teresa de Jesús ${ }^{1}$
}

\author{
María Leticia SÁNCHEz HeRnÁNDEZ \\ Patrimonio Nacional \\ leticia.sanchez@patrimonionacional.es
}

Fecha de recepción: 20/12/2014

Fecha de aceptación: 24/03/2015

\section{RESUMEN}

En el V centenario del nacimiento de Teresa de Jesús (1515-2015), vamos a hacer un recorrido por la realidad más cotidiana de su vida y de su entorno: la enfermedad y los remedios terapéuticos. A través de la lectura y el comentario de una selección de sus escritos, se analizarán las dolencias y las formas de sanación de la vida femenina conventual del siglo XVI, comprendidas en el contexto concreto que imponen las condiciones materiales de la clausura perpetua, como son clima, hábitat, alimentación, e indumentaria. La experiencia mística de Teresa está radicalmente unida con la experiencia de la enfermedad, que la acompañó desde antes de profesar en el Carmelo.

Palabras clave: Teresa de Jesús, escritura conventual femenina, enfermedad, remedios, alimentación, arquitectura conventual.

\section{Some Notes on Diseases and Remedies of Teresa de Jesús}

\begin{abstract}
In the 5th centenary of Teresa de Jesús' birth (1515-2015), let's take a tour of the more everyday reality of her life and of her environment: illness and therapeutic remedies. Through reading and commentary of a selection of her writings, will analyse the ailments and healing of 16th-century feminine convent life forms, in the concrete context imposed by the material conditions of the perpetual closure, such as climate, habitat, food, and clothing. The mystical experience of Teresa is radically linked with the experience of the disease, who accompanied from before profess in Carmel.
\end{abstract}

Key words: Teresa de Jesús, Female Convent Writing, Illness, Remedies, Nutrition, Conventual Architecture.

1 Este trabajo se inscribe en el proyecto I+D HAR2011-26435- c03-01, El hecho cotidiano en la Monarquía Española de la Edad Moderna: lo doméstico entre lo privado y lo público. Historia comparada entre el interior y la periferia. Dirigido por la profesora Gloria Franco Rubio de la Universidad Complutense. 


\section{ENFERMEDADES Y DOLENCIAS EN LOS CARMELOS TERESIANOS}

Una de las realidades que tienen una radical influencia en la existencia, y por ende en la escritura de la Edad Moderna, es la enfermedad, constantemente presente en los monasterios. Tan asumido e integrado está el tema del dolor y de la mortalidad, que ambas realidades son dos compañeras inseparables en la vida de toda persona de los siglos XVI y XVII. Teresa da cuenta de sus propias enfermedades, de las enfermedades de sus monjas, de las enfermedades de prioras y monjas de otros conventos, de los achaques de confesores y de personas que se relacionan con los conventos, y de los males de la casa real y de las personas relacionadas con la casa real ${ }^{2}$. La actividad epistolar va a ser una de las principales fuentes documentales para el estudio de la vida monástica femenina en su vertiente cotidiana, dando lugar a la creación de redes entre conventos, y de redes entre conventos y las esferas de poder civil, religioso, y cultural. Las cartas teresianas son una ventana a la historia del siglo XVI, y ayudan a conocer a esta mujer en su contexto más inmediato. El epistolario comienza donde terminan las obras mayores: se puede afirmar que es la concreción de su doctrina, porque solo a través de la Teresa más cotidiana, de la Teresa en su faceta de enferma, se descubre su vivencia mística. Leyendo el epistolario, el Libro de la Vida, y el Libro de las Fundaciones, siempre está presente la enfermedad, aunque sea como telón de fondo ${ }^{3}$ :

A mí me ha probado la tierra de manera, que no parece nací en ella, no creo he tenido mes y medio de salud al principio [...] tres semanas ha que sobre las cuartanas me dio dolor de un lado y esquinancia; El uno de estos males bastaba para matar... con tres sangrías estoy mejor. Quitaronseme las cuartanas, más la calentura nunca se quita y ansí me purgo mañana. Estoy ya enfadada de verme tan perdida, que si no es a misa, no salgo de un rincón, ni puedo. Un dolor de quijadas que ha cerca de mes y medio que tengo ${ }^{4}$; Cuando no tengo más que los males ordinarios es mucha salud ${ }^{5}$; Algunas veces estoy fatigada de verme para tan poco en su servicio y de ver que por fuerza he de ocupar el tiempo en cuerpo tan flaco y ruin como el mío más de lo que yo querría. Estaba una vez en oración y vino la hora de ir a dormir, y yo estaba con hartos dolores y había de tener el vómito ordinario. Como me vi tan atada de mí y el espíritu

2 ARÍSTEGUI BILBAO, P.: Santa Teresa de Jesús enfermera (la salud corporal en sus obras y escritos), Vitoria, editorial del Seminario, 1952. IZQUIERDO HERNÁNDEZ, M.: Santa Teresa de Jesús. Enfermedades y muerte, Madrid, eds. Iberoamericanas, 1963 , fueron dos de los primeros estudios sobre el tema. MADRE DE DIOS, E. y STEGGINK, O.: Tiempo y vida de Santa Teresa, Madrid, Bac, 1996, pp.109-134 recopilaron las interpretaciones hechas sobre algunas de sus enfermedades. Partiendo de los textos de Teresa y teniendo en cuenta los estudios citados, presentamos la sistematización de sus enfermedades y de los remedios empleados con interpretaciones recientes y con las indicaciones del Servicio de Medicina Interna del Hospital General Universitario Gregorio Marañón de Madrid.

3 La edición utilizada de los escritos de Santa Teresa es, MADRE DE DIOS, E. y STEGGINK, O., (eds.): Santa Teresa de Jesús: Obras Completas, Madrid, Bac, 1986. Las siglas para las obras son las siguientes: Cta (carta), que se citará con el número de la edición, la identidad del destinatario, el lugar desde el que se escribe, y la fecha; F (Libro de las Fundaciones); V (Libro de la Vida); M (Las Moradas); Cp (Camino de Perfección); $\mathrm{Cc}$ (Cuentas de Conciencia); C (Constituciones)

4 Cta 39.3: María de Mendoza. Ávila, 7-3-1572.

5 Cta 65.4: Antonio Gaitán. Segovia, 30-5-1574. 
por otra parte queriendo tiempo para sí, vime tan fatigada, que comencé a llorar mucho y a afligirme ${ }^{6}$.

Teresa describe diferentes tipos de enfermedades a lo largo de toda su obra ${ }^{7}$. Los dos textos anteriores enumeran alguna de las dolencias y remedios más frecuentes del momento, tales como cuartanas, calentura, dolor de lado, esquinancia, dolor de quijadas, y vómito; así como dos de los tratamientos más habituales: sangrías y purgas. Es una constante el comentario sobre la presencia de calenturas o calenturillas, término genérico que sirve para designar fiebres, paludismo, e incluso insolación. Calentura es la fiebre en cuanto que es calurosa y ardiente $^{8}$, que puede ser cotidiana, continua, perpetua, terciana, cuartana, o de India efímera.

Un día antes de Pascua de Espíritu Santo les dio Dios un trabajo harto grande, que fue darme a mí una muy recia calentura. Yo creo que sus clamores a Dios fueron bastantes para que no fuese adelante el mal; que jamás de tal manera en mi vida me ha dado calentura que no pase muy más adelante. Fue de tal suerte, que parecía tenía modorra, según iba enajenada. Ellas a echarme agua en el rostro, tan caliente del sol, que daba poco refrigerio ${ }^{9}$; Antes de Navidad me dieron unas calenturas y estuve de mal de garganta, sangrada dos veces y purgada. Desde antes de los Reyes tengo cuartanas... esfuérzome a no estar en la cama, sino con calentura, que es toda la noche ${ }^{10}$.

Las tercianas son fiebres intermitentes y escalofríos causados por el plasmodium vivax -paludismo- en que los accesos aparecen al tercer día separados por un día de apirexia completa; las tercianas dobles son dos accesos cada dos días. "General han sido estas tercianas. Acá no hay otra cosa, aunque a mí me han dejado" ". "Son sencillas las tercianas que tiene, no hay que tener pena" ${ }^{12}$. Las cuartanas son también fiebres intermitentes, donde los accesos aparecen al cuarto día, dejando entre ellos dos días de intervalo. A veces la fiebre es sintomática de una supuración profunda (hepatitis supurada, infección urinaria, endocarditis ulcerosa, infección purulenta); pero casi siempre obedece a la infección palúdica y por ello este término se adopta a menudo como sinónimo de paludismo:

Las mis cuartanas lo van, y lo peor es que torna el dolor de estotros inviernos, que la noche pasada dormí bien poco de él ${ }^{13}$; Recios fríos, cuartanas dobles, dolores incomparables, hastío muy grande ${ }^{14}$; Ha cuarenta años que no tuve tanta salud. Ha un

\footnotetext{
$6 \mathrm{~V} 40.20$

7 El estudio de las escritoras conventuales femeninas españolas se inscribe en el proyecto I+D+i FF1201232764, Bieses: balance y nuevos modelos de interpretación, dirigido por la profesora Nieves Baranda Leturio. 2013-2015.

8 COVARRUBIAS, S. de: Tesoro de la lengua castellana o española, Madrid, Luis Sánchez impresor del rey, MDCXI, p.175.

9 F 24.7.

10 Cta 37.2: Juana de Ahumada. Ávila, 4-2-1572.

11 Cta 43.1: Juana de Ahumada. Ávila, fin de 1572.

12 Cta 289.9: María Bautista. Ávila, 21-6-1579.

13 Cta 56.1: Juana de Ahumada. Salamanca, 14-11-1573.

14 V 6.1.
} 
año que tuve unas cuartanas, estaba en Valladolid ${ }^{15}$; Siento un poco de frío, que es día de cuartana ${ }^{16}$.

Otra variante de la fiebre es el tabardillo, que consiste en una fiebre aguda endémica, sin causa aparente, que puede confundirse con tifus y fiebre tifoidea; es una dolencia parecida al tifus con fiebre alta y continua, alteraciones nerviosas y sanguíneas, y una erupción que cubre todo el cuerpo. Era considerado un mal muy peligroso, porque salían unas pintas leonadas o negras y coloradas, siendo las de color encarnado más fáciles de curar ${ }^{17}$ : "El padre Nicolao ha estado malo de tabardillo" 18.

Dolor de lado es molestia en el costado, que puede estar provocado por un trombo embolismo pulmonar causado a partir de los cuarenta o cincuenta años por problemas circulatorios.

La esquinancia es inflamación de las amígdalas, o enfermedad que da en la garganta, muchas veces llamado también mal de garganta ${ }^{19}$. Si la inflamación se denomina garrote, o garrotillo, se trata de una difteria en la laringe procedente de la infancia:

Antes de Navidad me dieron unas calenturas y estuve de mal de garganta, sangrada dos veces y purgada. Desde antes de los Reyes tengo cuartanas... esfuérzome a no estar en la cama sino con la calentura, que es toda la noche ${ }^{20}$; Yo iba con un mal de garganta bien apretado que me dio camino en llegando a Valladolid, y sin quitárseme calentura. Comer, era el dolor harto grande. Esto me hizo no gozar tanto del gusto de los sucesos de este camino. Este mal me duró hasta ahora, que es a fin de junio, aunque no tan apretado, con mucho, mas harto penoso ${ }^{21}$; Y así, ya que estaba tan apretada, que duró poco y con dolores muy excesivos y una postema que me dio dentro de la garganta que no me dejaba tragar ${ }^{22}$, (en este caso se está refiriendo al dolor de quijada o maxilar inferior, o el encaje de las muelas y dientes) ${ }^{23}$ : Me ha dado un mal de quijadas y se me ha hinchado un poco el rostro ${ }^{24}$; Del que tiene vuestra merced de muelas me pesa mucho, porque tengo harta experiencia de cuan sentible dolor es. Si tiene vuestra merced alguna dañada suele parecer lo están todas, digo de dolor. Yo no hallaba mejor remedio que sacarla, aunque si son reúmas no aprovecha ${ }^{25}$.

Aparece el término postema (ya empleado por Plinio, Villegas, o Nieremberg), que es un absceso purulento ${ }^{26}$-en el caso de la garganta es un ganglio inflamado- llamado por distintos autores tumor que puede estar localizado en diferentes partes del cuerpo (Cicerón y Séneca), lobanillo (Mexía), hinchazón (Hernando de Soto), o papera

\footnotetext{
15 Cta 25.6: Lorenzo Cepeda. Toledo 17-1-1570.

16 Cta 57.2: Domingo Báñez. Salamanca, enero 1574.

17 COVARRUBIAS, op, cit. (nota 8), p.40.

18 Cta 389.5: María de San José. Villacastín, 5-9-1570.

19 COVARRUBIAS, op, cit. (nota 8), p.381.

20 Cta 37.2: Juana de Ahumada. Ávila, 4-2-1572.

21 F 31.17.

22 F 12.5

23 COVARRUBIAS, op, cit. (nota 8), p.602v.

24 Cta 75.3: Catalina Hurtado. Ávila, 31-10-1574.

25 Cta 393.4: Sancho Dávila. Ávila, 9-10-1581.

26 COVARRUBIAS, op.cit. (nota 8), p.593v.
} 
(Nieremberg) 27: "Y ha sido tan poca mi salud, que desde el jueves de la cena no se me ha quitado calentura hasta ahora ocho días. Y tenerla era el menor mal, según lo he pasado. Decían los médicos que se hacía un postema en el hígado; con sangrías y purgas ha sido Dios servido de dejarme en este piélago de trabajos" ${ }^{28}$. Los abscesos hay que sajarlos y ya desde antiguo se emplearon diferentes instrumentos, entre los que se mencionan cuchillo, espada, alfanje, e incluso flecha:

Diole luego una postema dentro de las tripas con tan gravísimos dolores, que era bien menester para sufrirlos con paciencia lo que el Señor había puesto en su alma. Esta postema era por la parte de adentro, adonde cosa de las medicinas que la hacían no la aprovechaba; hasta que el Señor quiso que se la viniese a abrir y echar la materia, y así mejoró algo de este mal [...] Y así, ya que estaba tan apretada, que duró poco y con dolores muy excesivos y una postema que le dio dentro de la garganta que no la dejaba tragar ${ }^{29}$.

Junto con la calentura suele hacer acto de presencia la perlesía, que es una parálisis acompañada de temblores producida por falta de calcio, o por la edad, algunos autores la identifican con un parkinson incipiente:

Desde el jueves de la cena me dio un accidente de los grandes que he tenido en mi vida de perlesía y corazón. Dejóme hasta ahora calentura y con tal indisposición y flaqueza ${ }^{30}$; Los achaques ordinarios son la perlesía, pero si no hay calentura, es estar buena [...] Aunque la calentura es poca, los accidentes del corazón y de la matriz son muchos $^{31}$; Y casi nunca estoy, a mi parecer, sin muchos dolores, y algunas veces bien graves, en especial en el corazón, aunque el mal que me tomaba muy continuo es muy de tarde en tarde. Perlesía recia y otras enfermedades de calenturas que solía tener muchas veces, me hallo buena ocho años ha. De estos males se me da ya tan poco, que muchas veces me huelgo, pareciéndome en algo se sirve el Señor ${ }^{32}$.

El romadizo es un catarro de la membrana pituitiaria, descrita como destilación que cae de la cabeza a la garganta y al pecho ${ }^{33}$ : "He tenido tres semanas ha un romadizo terrible con hartas indisposiciones" 34 ; "Detuveme allí cuatro días (en Valladolid) por un gran catarro con un poco de perlesía ${ }^{35}$; Desde anoche que recibí esas (cartas) de Malagón, me ha cargado un gran romadizo que tenía, como me cansé en leer y escribir" 36 . En 1580 tuvo lugar el llamado gran catarro, reconocido por muchos autores como la primera epidemia de gripe de diseminación global, aunque otros

27 FRADEJAS LEBRERO, J.: “La postema. Origen y evolución”, Príncipe de Viana, anejo, 18 (2000), pp. 127-136.

28 Cta 328.1: Duquesa de Alba. Toledo, 8-5-1580.

29 F 12.4.Relata la enfermedad de Beatriz de la Encarnación, monja en el Carmelo de Valladolid.

30 Cta 321.2 y 12: María de San José. Toledo, 3-4-1580.

31 Cta 340.2: Gaspar Daza. Valladolid, 8-9-1580.

$32 \mathrm{~V} 7.11$.

33 COVARRUBIAS, op, cit. (nota 8), p.14v y 211.

34 Cta 68.2: Postulantas. Segovia, marzo 1574.

35 Cta 414.1: Catalina de Tolosa. Palencia, 16-1-1582.

36 Cta 235.1: Jerónimo Gracián. Ávila, 14-5-1578. 
hablan de tos ferina; la citada epidemia comenzó en Asia y de allí pasó a Europa y América. Casi toda Europa fue afectada en seis semanas, y se dice que solo el veinte por ciento de la población escapó de la enfermedad. Transcurridos entre siete y diez días de incubación, se suceden tres etapas; la primera o catarral, con sintomatología parecida a un catarro común: rinorrea serosa, estornudos, malestar general, anorexia y fiebres. Después de una o dos semanas, aparecen períodos de tos repetida seguidas de un estridor respiratorio, que culmina en vómitos y estado de agotamiento. Después de dos a cuatro semanas, la enfermedad entra en la tercera y última etapa o de convalecencia. En los años ochenta se empezaba a producir una oscilación climática con incremento de los episodios de lluvia extremos, temporales, grandes nevadas, y olas de frío que influyeron negativamente en la población. Felipe II y Ana de Austria se infectaron, tal y como se recogió en la memoria de monjes jerónimos de El Escorial: el rey estuvo al borde de la muerte, pero su cuarta esposa murió embarazada ${ }^{37}$. Teresa de Jesús también estuvo afectada por esta epidemia, que la tuvo al borde de la muerte, y que la obligó a presenciar muchas muertes en su entorno: "Y no sé para qué me deja Dios sino para ver muertes este año de siervos de Dios, que me es harto tormento" 38 . La influencia del clima fue decisivo para ella. Reconoció, a su pesar, que Ávila le sentó siempre mal: "Dios me libre de él (se refiere a Galinduste, en la comarca de Alba de Tormes, donde está su hermana Juana) y aun de éste también (Ávila), que desde que vine tengo poca salud" ${ }^{39}$, además de los fríos abulenses cree que hay algún factor, alimentos y plantas locales que le dañan la salud, posiblemente sean el ciprés y el olivo de la Encarnación. Sin embargo, también reconoció, muy a su pesar, que el clima de Sevilla le sentaba muy bien, aunque la ciudad y sus costumbres no fueran de su agrado: "Yo tengo salud, Gloria a Dios, y me va bien esta tierra" ${ }^{40}$. Siguiendo la descripción de sus enfermedades, los catarros y las calenturas sucedían siempre en tierras castellanas, mientras que en los Carmelos de Beas y Sevilla mejoraba:

Porque ir yo a Burgos con tantas enfermedades, que les son los fríos muy contrarios, siendo tan frío, parecióme que no se sufría, que era temeridad andar tan largo camino, acabada casi de venir de tan áspero -como he dicho- en la venida de Soria, ni el padre Provincial me dejaría ${ }^{41}$. No pongo en estas fundaciones los grandes trabajos de los caminos, con fríos, con soles, con nieves, que tenía vez no cesarnos en todo el día de nevar, otras perder el camino, otras con hartos males y calenturas, porque, gloria a Dios, de ordinario es tener yo poca salud, sino que veía claro que nuestro Señor me daba esfuerzo ${ }^{42}$.

Habla asimismo de flujos del estómago, que son hemorragias digestivas provocadas por vómitos importantes, por úlcera, o por un cáncer gástrico, que pueden ir

\footnotetext{
37 CAMAÑO PUIG, R. BARRIENDOS VALlVÉ, M. y FAUS GABANDÍ, F.: "El Gran Catharro de 1580: ¿Gripe o pertussis?” Asclepio, vol LVII-2 (2005), pp. 45-58.

38 Cta 343: María de San José. Valladolid, 25-10-1580.

39 Cta 37.1: Juana de Ahumada. Ávila, 2-2-1578.

40 Cta 83.3: Inés Niet. Sevilla, 19-6-1575.

41 F 31.11.

42 F 18.4 .
} 
acompañados por bascas o retortijones en el estómago que inducen al vómito: “Algunas veces no puedo estar sentada, según me dan vascas" ${ }^{43}$ :

Algunas veces estoy fatigada de verme para tan poco en su servicio y de ver que por fuerza he de ocupar el tiempo en cuerpo tan flaco y ruin como el mío más de lo que yo querría. Estaba una vez en oración y vino la hora de ir a dormir, y yo estaba con hartos dolores y había de tener el vómito ordinario. Como me vi tan atada de mí y el espíritu por otra parte queriendo tiempo para sí, vime tan fatigada, que comencé a llorar mucho y a afligirme ${ }^{44}$.

En bastantes textos las enfermedades no se especifican, pues únicamente habla de grandes dolores como mal de riñones, dolor de espalda, dolor en los pulsos, reúmas, o mal de ojos. En general el empleo del término achaque hace referencia a una indisposición, aunque no rinda del todo a la persona, ni le derrueque en la cama, sino que el malestar se pasa de pie ${ }^{45}$. Tener pulso es un movimiento o golpe de las arterías causado por el corazón, y quedar sin pulsos es la situación de la persona que se ha espantado o admirado de algo $^{46}$ :

Algunas veces se me quitan todos los pulsos casi, según dicen las que algunas veces se llegan a mí de las hermanas que ya más lo entienden, y las canillas muy abiertas, y las manos tan yertas que yo no las puedo algunas veces juntar; y así me queda dolor hasta otro día en los pulsos y en el cuerpo, que parece me han descoyuntado ${ }^{47}$.

Por mal de ojos puede entenderse cataratas o tracoma, muy frecuente en los siglos XVI y XVII, y caracterizado por una conjuntivitis granulosa que podía desembocar en ceguera; los problemas oculares se curaban con aceites fuertes y corrosivos para paliar el humor de los ojos. Las molestias oculares imprecisas están también relacionadas con las cefaleas provocadas por la mala alimentación, la anemia provocada por la práctica de las constantes sangrías, y las permanentes calenturas.

Los mareos y el desflaquecimiento se emplean para expresar un estado de desmejoramiento, desgana, desmayo, que significa perder las fuerzas y el sentido, o deliquio del ánimo ${ }^{48}$ también utilizado para indicar el estado del cuerpo después de una sangría:

Cuando hay flaqueza, se siente un desmayo que ni deja hablar ni menear: no se resiste $^{49}$; La cabeza está tan flaca que aun de notar me canso, porque no ha sido ésta hoy sola. Fue tan grande el hastío, que me enflaqueció más que las calenturas ${ }^{50}$; Habíanme dado con unas calenturas, grandes desmayos, que siempre tenía bien poca salud ${ }^{51}$. 
La hidropesía o retención de líquidos en los tejidos es la acumulación de líquido en el peritoneo -en el vientre-, aunque también se da en los tobillos y muñecas, brazos y cuello. Covarrubias habla de enfermedad de humor aguoso que hincha todo el cuer$\mathrm{po}^{52}$. No constituye una enfermedad independiente, sino que es un síntoma clínico que acompaña a diversas enfermedades del corazón, riñones, y aparato digestivo, con las que mantiene la íntima relación de efecto a causa, como consecuencia de un mal funcionamiento de las funciones digestivas y eliminadoras de los riñones y la piel. Si la cantidad de líquido es mucha, se producen trastornos en corazón y pulmones debido a la presión que se ejerce sobre estos órganos. Cuando la retención de agua es en el vientre, puede estar motivado por tuberculosis, tumores del intestino, tumores del aparato genital femenino, así como por enfermedades o alteraciones funcionales del corazón, del hígado, y de los riñones. Cuando la retención es causada en pies y piernas -edema-, aparece la hinchazón típica, sin dar origen a dolores de ningún tipo, ni alterar el color habitual de la piel.

El cuadro médico de Catalina Godínez es un ejemplo de las dolencias que estamos relatando ${ }^{53}$ :

En estos ejercicios pasó cerca de cuatro años, que comenzó el Señor a que le sirviese en otros mayores, dándole grandísimas enfermedades y muy penosas, así de estar con calentura continua y con hidropesía y mal de corazón; un zaratán que le sacaron. En fin, duraron estas enfermedades casi diecisiete años, que pocos días estaba buena [...] En este tiempo tenía calentura continua ocho años había, hética y tísica, hidrópica, con un fuego en el hígado que se abrasaba, de suerte que aun sobre la ropa era el fuego de suerte, que se sentía y le quemaba la camisa, cosa que parece no creedera, y yo misma me informé del médico de estas enfermedades que a la sazón tenía, que estaba harto espantado. Tenía también gota artética y ciática.

Además de hidropesía y calentura, sus enfermedades se amplían a mal de corazón, zaratán, tisis, gota y ciática. En los siglos XVI y XVII se entendía por mal de corazón una dolencia prolongada en el músculo cardíaco de origen desconocido, provocado, según se creía, por un gran esfuerzo o por el simple cansancio: "Hame dado pena ese mal que dice que tiene de corazón, que es muy penoso... de una cosa se alegre, que en el alma está muy más aprovechada" ${ }^{4}$. El zaratán o çaratán es cáncer de mama, que según Covarrubias es el que nace a las mujeres en el pecho, y solo puede curarlas la navaja, cortando por la parte viva y sana, porque no se pase adelante (metástasis) ${ }^{55}$. Estar hética significa que padece la enfermedad de la tisis, que se caracteriza por una consunción gradual y lenta acompañada de fiebre y de ulceración en algún órgano, tiene su asiento en los pulmones y los pacientes se van secando ${ }^{56}$. Tísis es el nombre

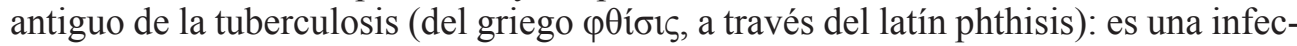
ción bacteriana contagiosa que compromete principalmente los pulmones, pero puede propagarse a otros órganos. La especie de bacterias más importante y representativa

52 COVARRUBIAS, op, cit. (nota 8), p.469.

53 F 22.12. Son las enfermedades de Catalina Godínez en el Carmelo de Beas de Segura.

54 Cta 237.8: María de San José. Ávila, 4-6-1578.

55 COVARRUBIAS, op.cit. (nota 8), p.185 v.

56 Ibidem, p.45. 
causante de tuberculosis es Mycobacterium tuberculosis o bacilo de Koch. Aunque la tuberculosis es una enfermedad predominantemente de los pulmones, puede afectar también el sistema nervioso central, el sistema linfático, el sistema circulatorio, el sistema genitourinario, el aparato digestivo, los huesos, las articulaciones y aun la piel. Según los médicos de Malagón, todos los síntomas que presentaba Brianda de San José eran de tisis, aunque ella insistía en que la llaga no era en los pulmones. Gota es un tipo de artritis que ocurre cuando el ácido úrico se acumula en la sangre y causa inflamación articular. Se entendía que era una enfermedad que acudía a las coyunturas, cayendo y corriendo su deflujo con intensos dolores; se consideraba la enfermedad de los $\operatorname{ricos}^{57}$, que eran los que podían acceder a la ingesta de carne roja. La gota aguda es una afección dolorosa que normalmente afecta a una articulación, mientras que la gota crónica corresponde a episodios repetitivos de dolor e inflamación que pueden afectar a más de una articulación. Las articulaciones afectadas con mayor frecuencia son los dedos gordos del pie, la rodilla, o el tobillo, que aparecen calientes, enrojecidas, e hinchadas, produciendo una deformación en las mismas. El dolor se describe como pulsátil e insoportable, y puede estar acompañado de un cuadro febril.

En las Navidades de 1577, estando en San José de Ávila, Teresa se cayó por las escaleras, fracturándose la mano y un brazo, y en este caso volvió a recurrir a los oficios de una curandera, que logró colocarle los huesos en su sitio. Sin embargo, a partir de este momento tuvo que ayudarse de dos amanuenses para la redacción de las cartas: Ana de San Bartolomé y Beatriz de Santo Domingo: "Todavía está hinchado (el brazo) y la mano, y con un socrocio que parece arnés"58; el socrocio es un emplasto de azafrán, que debía de ser tan voluminoso, que con mucha chispa lo compara con una armadura. "La mujer vino a curarme el brazo, que lo hizo muy bien la priora de Medina en enviarla, que no le costó poco ni a mí el curarme. Tenía perdida la muñeca, y ansí fue terrible el dolor y trabajo, como había tanto que caí [...] más menease bien la mano y el brazo puedo levantar a la cabeza" ${ }^{59}$. En julio de 1578 todavía no puede vestirse y lo que mejor le va es el calor ${ }^{60}$.

Una de las dolencias que más le preocuparon fue la llamada melancolía, sinónimo de neurastenia y depresión. Fue una dolencia conocida donde había poco contento y gusto, al producirse la alienación de la mente ${ }^{61}$. La fundadora quería mujeres con un equilibrio de todas las facultades, y ante la manifestación de estos síntomas recomendaba mantener ocupada a la monja, para que no se dejara arrastrar por la imaginación, a la vez que debía de moderarse en los ayunos. Las melancólicas debían de tratarse con mano dura, sin reparar en las reprimendas: "En lo que toca a la hermana de la madre Brianda de San José, ni para freila ni para monja no será; no porque no tiene ella muy bien entendimiento y buena razón y sosiego [...] que tenga algunos trabajos" "62. El caso de Isabel de Santo Domingo en Medina del Campo fue sintomático. Las carmelitas de Salamanca le pidieron a la Madre que las ilustrara sobre esta

57 Ibidem, p.444 v.

58 Cta 219.1: Jerónimo Gracián. Ávila, 12-2-1578.

59 Cta 233.7: Jerónimo Gracián. Ávila, 7-5-1578.

60 Cta 239.5: Domingo Báñez. Ávila, 28-7-1578.

61 COVARRUBIAS, op.cit. (nota 8), p.544 v.

62 Cta 449.4: Ana de los Ángeles. Valladolid, 2-9-1582. 
enfermedad, indicando cómo proceder con unas mujeres cuyo mal no es propiamente físico, aunque pueda tener consecuencias corporales. Teresa habló de este mal en varios de sus escritos:

He pensado que en estas casas y en todas las de Religión no se había de tomar este nombre en la boca, porque parece que trae consigo libertad, sino que se llame enfermedad grave - iy cuánto lo es!- y se cure como tal. Que a tiempos es muy necesario adelgazar el humor con alguna cosa de medicina para poderse sufrir; y estése en la enfermería, y entienda que, cuando saliere a andar en comunidad, que ha de ser humilde como todas y obedecer como todas; y cuando no lo hiciere que no le valdrá el humor; [...] Las prioras han menester, sin que las mismas lo entiendan, llevarlas con mucha piedad, así como verdadera madre, y buscar los medios que pudiere para su remedio ${ }^{63}$.

Y han de advertir que el mayor remedio que tienen es ocuparlas mucho en oficios para que no tengan lugar de estar imaginando, que aquí está todo su mal; y aunque no los hagan tan bien, súfranlas algunas faltas, por no las sufrir otras mayores estando perdidas, $[\ldots]$ y procurar que no tengan muchos ratos de oración, aun de lo ordinario; que, por la mayor parte, tienen la imaginación flaca y haráles mucho daño, y sin eso se les antojarán cosas que ellas ni quien las oyere no lo acaben de entender. Téngase cuenta con que no coman pescado, sino pocas veces; y también en los ayunos es menester no ser tan continuos como las demás ${ }^{64}$.

Parece están buenas, porque ellas no quieren conocer tienen este mal; y como no las fuerza a estar en cama, porque no tienen calentura, ni a llamar médico, es menester lo sea la priora; [...] con otras enfermedades o sanan o se mueren; de ésta, por maravilla sanan, ni de ella se mueren, sino vienen a perder del todo el juicio, que es morir para matar a todas ${ }^{65}$.

Por eso tengan aviso que cuando sintieren esto en sí, lo digan a la prelada [...] y procure que duerman bien y coman, hasta que se les vaya tornando la fuerza natural [...] Si es de tan flaco natural que no le baste esto, créanme que no la quiere Dios sino para la vida activa, que de todo ha de haber en los monasterios ${ }^{66}$.

\section{LAS ENFERMEDADES DE 1538 Y 1582}

En el verano de 1538 empezó a sentirse mal, y ella misma lo atribuyó a la ingesta de algún alimento ${ }^{67}$.

La mudanza de la vida y de los manjares me hizo daño a la salud, que, aunque el contento era mucho, no bastó. Comenzáronme a crecer los desmayos y diome un mal de corazón tan grandísimo, que ponía espanto a quien le veía, y otros muchos males juntos, y así pasé el primer año con harta mala salud [...] Y como era el mal tan grave

\footnotetext{
63 F 7.5.

64 F 5.9.

65 F 5.10.

$66 \mathrm{M} 4.3 .13$.

67 Muy sugerente y actual por la exactitud de las interpretaciones de las dos enfermedades citadas es la obra de SENRA VARELA, A.: Las enfermedades de Santa Teresa de Jesús, Madrid-Buenos Aires, Díaz de Santos, 2006. Véase también, PÉREZ, J.: Teresa de Ávila y la España de su tiempo, Madrid, Alcaba ediciones, 2007; ROS, C.: Teresa de Jesús, esa mujer, Madrid, San Pablo, 2011.
} 
que casi me privaba el sentido siempre y algunas veces del todo quedaba sin él, era grande la diligencia que traía mi padre para buscar remedio; y como no le dieron los médicos de aquí, procuró llevarme a un lugar adonde había mucha fama de que sanaban allí otras enfermedades, y así dijeron harían la mía ${ }^{68}$.

Tomaba queso y leche de cabra procedentes de los rebaños de cabras de su madre de Gotarrendura. El mal le privaba el sentido, tenía mareos o síncopes, aunque no se puede hablar de ataques convulsivos, por la corta duración. Proceso febril prolongado, dolor precordial (pericarditis que se acompaña de pérdidas de conocimiento momentáneas: el corazón de la santa presenta una cicatriz en superficie), y dolores lumbares y de extremidades generalizados desde el principio. Los síntomas son de brucelosis o fiebres de malta, una infección provocada por la ingesta de leche y queso de cabra. A ella se le complicó y desembocó en neurobrucelosis, es decir, que las bacterias de la leche de cabra penetraron hasta el sistema nervioso central. Ávila era una de las zonas con mayor producción de leche de cabra, y una de las zonas con el índice más alto de brucelosis.

En otoño de 1538 salió gravemente enferma de la Encarnación para ser tratada por una curandera de Becedas especialista en intestinos. Ésta necesitaba unas hierbas purgantes y diuréticas que sólo crecían en primavera, por eso no la pudo tratar hasta 1539.

Estuve casi un año por allá, y los tres meses de él padeciendo tan grandísimo tormento en las curas que me hicieron tan recias, que yo no sé cómo las pude sufrir; y en fin, aunque las sufrí, no las pudo sufrir mi sujeto, como diré. Había de comenzarse la cura en el principio del verano, y yo fui en el principio del invierno. Todo este tiempo estuve en casa de la hermana que he dicho que estaba en la aldea, esperando el mes de abril, porque estaba cerca, y no andar yendo y viniendo ${ }^{69}$.

La curandera fue nociva, porque le provocó anemia y desnutrición con la administración de una purga diaria, durante un mes, en la que mezclaba hierbas, uñas de rana, alas de mosca pulverizadas, y excrementos de culebra. El empeoramiento fue progresivo, porque la fiebre no bajaba y no podía tragar sólido.

Estuve en aquel lugar tres meses con grandísimos trabajos, porque la cura fue más recia que pedía mi complexión. A los dos meses, a poder de medicinas, me tenía casi acabada la vida, y el rigor del mal de corazón de que me fui a curar era mucho más recio, que algunas veces me parecía con dientes agudos me asían de él, tanto que se temió era rabia. Con la falta grande de virtud (porque ninguna cosa podía comer, si no era bebida, de grande hastío) calentura muy continua, y tan gastada, porque casi un mes me había dado una purga cada día, estaba tan abrasada, que se me comenzaron a encoger los nervios con dolores tan incomportables, que día ni noche ningún sosiego podía tener. Una tristeza muy profunda ${ }^{70}$.

\footnotetext{
$68 \mathrm{~V} 4.5$.

$69 \mathrm{~V} 4.6$.

70 V 5.7.
} 
Teresa habla de fiebre continua u ondulante en forma de cuartanas -la fiebre entonces solo se medía poniendo la mano en la frente-, llamada en Castilla fiebre tonta, que se acompaña de dolores musculares. Asimismo, expresa la dificultad para tragar sólidos debido a la disfagia provocada por los tóxicos de las hierbas. Se le empezaron a encoger los músculos con dolores (polineuritis o polirradiculitis) espasmódicos por el abuso de purgantes: y cuando habla del estado de tristeza se refiere al intenso malestar.

Con esta ganancia me tornó a traer mi padre adonde tornaron a verme médicos. Todos me desahuciaron, que decían sobre todo este mal, decían estaba hética. De esto se me daba a mí poco. Los dolores eran los que me fatigaban, porque eran en un ser desde los pies hasta la cabeza; porque de nervios son intolerables, según decían los médicos, y como todos se encogían, cierto -si yo no lo hubiera por mi culpa perdido- era recio tormento $^{71}$.

Su padre decidió trasladarla a Ávila para ser tratada por los médicos. Éstos la vieron muy mal, en peligro de muerte -hética y tísica se utilizaban también para definir una persona que estaba muriendo-. En agosto de 1539 se agravó, y el 15 tuvo un ataque convulsivo, un parajismo dice, a partir del cual entró en coma profundo cuatro días: no tiene nada que ver con un ataque histérico - estamos ante una de las mujeres más equilibradas de su tiempo-, ni fue infección tuberculosa, ni paludismo mal curado, ni tampoco epilepsia, puesto que una convulsión de estas características, y esto se deduce de sus escritos, solo la padeció esta vez; el estado de coma solo se explica por un estado neurológico reversible. La creyeron muerta, y para comprobarlo le aplicaron cera hirviendo en los párpados, y el espejo en la boca.

Quedé de estos cuatro días de paroxismo de manera que solo el Señor puede saber los incomportables tormentos que sentía en mí: la lengua hecha pedazos de mordida; la garganta, de no haber pasado nada y de la gran flaqueza que me ahogaba, que aun el agua no podía pasar; toda me parecía estaba descoyuntada; con grandísimo desatino en la cabeza; toda encogida, hecha un ovillo, porque en esto paró el tormento de aquellos días, sin poderme menear, ni brazo ni pie ni mano ni cabeza, más que si estuviera muerta, si no me meneaban; sólo un dedo me parece podía menear de la mano derecha. Pues llegar a mí no había cómo, porque todo estaba tan lastimado que no lo podía sufrir. En una sábana, una de un cabo y otra de otro, me meneaban. Esto fue hasta Pascua Florida. Sólo tenía que, si no llegaban a mí, los dolores me cesaban muchas veces y, a cuento de descansar un poco, me contaba por buena, que traía temor me había de faltar la paciencia; y así quedé muy contenta de verme sin tan agudos y continuos dolores, aunque a los recios fríos de cuartanas dobles con que quedé, recísimas, los tenía incomportables; el hastío muy grande ${ }^{72}$.

La lengua mordida es una consecuencia de la convulsión. El desatino en la cabeza es un estado confusional postcomatoso, incluso un estado depresivo, propio de la salida del coma, que la mantiene obnubilada unos días. La posición de ovillo es típica

\footnotetext{
$71 \mathrm{~V} 5.8$.

72 V 6.1.
} 
de una meningitis aguda. Quedó paralítica y con intensos dolores durante tres años, y esto se debió a la afectación de los nervios motores periféricos por la polineutiris y la persistencia a la disfagia para sólidos: los estímulos externos provocan dolor: tenían que moverla tirando de una sábana. El hastío es un estado de desgana o astenia. Ese mismo agosto regresó a la Encarnación en un estado de caquexia extrema -desnutrición-. El mal estado le duró ocho meses, y el estar tullida tres años. Sin embargo, tuvo secuelas toda la vida.

Luego tan gran prisa de irme al monasterio, que me hice llevar así. A la que esperaban muerta, recibieron con alma; mas el cuerpo peor que muerto, para dar pena verle. El extremo de flaqueza no se puede decir, que solos los huesos tenía ya. Digo que estar así me duró más de ocho meses; el estar tullida, aunque iba mejorando, casi tres años. Cuando comencé a andar a gatas, alababa a Dios ${ }^{73}$.

Aunque sané de aquella tan grave, siempre hasta ahora las he tenido y tengo bien grandes, aunque de poco acá no con tanta reciedumbre, mas no se quitan, de muchas maneras. En especial tuve veinte años vómito por las mañanas, que hasta más de mediodía me acaecía no poder desayunarme; algunas veces, más tarde. Después acá que frecuento más a menudo las comuniones, es a la noche, antes que me acueste, con mucha más pena, que tengo yo de procurarle con plumas y otras cosas, porque si lo dejo, es mucho el mal que siento. Y casi nunca estoy, a mi parecer, sin muchos dolores, y algunas veces bien graves, en especial en el corazón, aunque el mal que me tomaba muy continuo es muy de tarde en tarde. Perlesía recia y otras enfermedades de calenturas que solía tener muchas veces, me hallo buena ocho años ha ${ }^{74}$.

No era la primera vez que le sucedía un accidente de este tipo, aunque no tan grave, ya que a los dieciocho meses de estar en el convento de Santa María de Gracia en Ávila -el lugar en el que la internó su padre para encauzar su vida- empezó a encontrarse enferma con síntomas similares a los descritos -languidez y desmayos-, pero en este caso no se describe la enfermedad de manera pormenorizada. También tuvo que sacarla de allí su padre y llevarla a casa de su hermana María de Cepeda. El trayecto lo hizo a duras penas, casi sin fuerzas para sostenerse en la montura.

A finales de 1582 sufrió su última enfermedad. Casi todas las referencias se tienen por terceras personas, principalmente por los relatos de Ana de San Bartolomé y de su sobrina Teresita, porque al tratarse de hemorragias genitales, entraba en juego un componente de pudor para describir ella misma su enfermedad. Comenzó a sentirse mal en Palencia, notando los primeros flujos (metrorragias), y por eso quiso marchar enseguida a San José de Ávila, el lugar donde esperaba morir a gusto. Sin embargo, al llegar a Medina del Campo recibió orden de sus superiores de trasladarse a Alba de Tormes para estar presente en el parto de la duquesa de Alba- doña María de Toledo-, al tiempo que asistía a la elección de priora en esa comunidad. El viaje a Alba fue muy duro, y su estado se agravó: las hemorragias se intensificaron, y la trataron a base de sangrías, que literalmente la dejaron exangüe. Las hemorragias genitales en una mujer de 67 años que no ha tenido vida sexual activa, se deben generalmente

\footnotetext{
$73 \mathrm{~V} 6.2$.

$74 \mathrm{~V} 7.11$
} 
a un tumor en el endometrio. Dice su sobrina Teresita que del quebrantamiento del camino echó mucha sangre, un derrame visceral de espantosas proporciones. Hacer diagnósticos sobre apreciaciones de este tipo es resbaladizo, pero con toda probabilidad falleció de un cáncer de útero agravado por las sangrías y la fuerte anemia ${ }^{75}$.

Y a la mañana siguiente nos partimos (camino de Alba desde Medina) sin llevar cosa alguna para el camino, y la Santa iba ya mala del mal de la muerte; y todo este día por el camino no pude hallar ninguna cosa para darla de comer. Y en una noche, estando en un pobre lugarcillo, no se halló cosa que comer, y ella se halló con gran flaqueza, y díjome: "Hija deme si tiene algo, que me desmayo", y yo no tenía cosa sino unos higos secos, y ella estaba con calentura. Yo di cuatro reales que me buscasen dos huevos costasen lo que costasen. Yo, cuando vi que por dinero no se hallaba cosa, y que me lo volvían, no podía mirar a la Santa sin llorar, que tenía el rostro medio muerto ${ }^{76}$.

Este día llegamos a Alba, y tan mala nuestra madre, que no estuvo para entretenerse con sus monjas. Dijo que se sentía tan quebrantada, que a su parecer no tenía un hueso sano. Desde este día, que era víspera de san Mateo, anduvo en pie con todo su trabajo hasta el día de san Miguel, que fue a comulgar. Viniendo de hacerlo, se echó luego en la cama, porque no venía para otra cosa, que le dio un flujo de sangre, de lo cual se entiende que murión ${ }^{77}$

\section{SISTEMAS DE CURACIÓN}

Los tratamientos aplicados en el entorno teresiano pueden dividirse en los siguientes bloques: medicamentos vía oral, medicamentos tópicos, e intervenciones quirúrgicas.

Por vía oral se administraban infusiones, jarabes y pastillas. Las infusiones eran de agua de azahar, agua rosada, zarzaparrilla, y escorzonera. El agua de azahar se hacía con pétalos de flor de azahar y otros cítricos, que ayudaban a eliminar gases, a conciliar el sueño, a relajar los músculos, y a purificar el hígado: "No me envíe cosa sino agua de azahar, pues se quebró la redoma (vasija en la que solía guardarse), y un poco de azahar, si puede ser de hoja, seco, en azúcar" 78; "Con el mal del brazo trayo el corazón harto malo algunos días; envíeme un poco de agua de azahar y sea de manera que no se quiebre en lo que viniere" 79 . De similares efectos es el agua rosada hecha con pétalos de rosa: "Mucho aprovecha por acá beber cuatro o cinco tragos de agua rosada. A mi gran provecho me hace, y de azahar mucho daño, y oler lo de azahar provecho al corazón, más no beberlo" "80; "Del anime (resina de cubaril traída de Las Indias) también se tomó un poco, que se lo quería yo enviar a pedir, que hacen unas pastillas con ello de azúcar rosado que me hacen un gran provecho para el reúma"81. Era frecuente el echar en el brasero pastillas de anime y azúcar rosado para aliviar el

\footnotetext{
75 MADRE DE DIOS, E. y STEGGINK, O., op.cit. (nota 2), pp. 925-947.

76 URKIZA; J. (ed.): Obras completas de la beata Ana de San Bartolomé, Burgos, Monte Carmelo, 1998, pp. 353-353.

77 Ibidem, p.66.

78 Cta 188.6: María de San José. Toledo, 9-4-1577. En Sevilla se planta el mejor azahar.

79 Cta 226.10: María de San José. Ávila, 28-5-1578.

80 Cta 316.5: María de San José. Malagón, 8 y 9-2-1580.

81 Cta 177.16: María de San José. Toledo, 2-1-1577.
} 
mal de cabeza y el reúma. El agua de zarzaparrilla (Smilaxaspera), también conocida como zarza morisca, es un arbusto de la familia de las smilcáceas, originario de Asia, África y Europa. Se trata de un arbusto de tallos delgados, volubles y espinosos, tiene hojas pecioladas, alternas, ásperas y con muchos nervios. Se utilizan en medicinas y en medicamentos sudoríficos y depurativos; tiene acción diurética y diaforética (que hace sudar); asimismo, es un tónico, depurativo, antiséptico, antibacteriano, antifúngica. Sin embargo, no parece que Santa Teresa fuera muy partidaria de este brebaje, porque consumido en dosis altas producía náuseas y vómitos: "Guárdense de beber el agua de zarzaparrilla, aunque más quite el mal de madre" 82 . Se introduce aquí el asunto de la histeria, llamada mal de madre durante los siglos XVI y XVII, en clara referencia a determinados síntomas funcionales y ataques convulsos atribuibles exclusivamente a las mujeres, cuyo origen físico -desde Hipócrates- se situaba en la matriz, pero que tenía también un componente psíquico en relación con ésta. En la Edad Media la matriz se llamaba madre, y se decía que el hisopo (hierba medicinal) ponía la madre en su lugar. "Tornóla avisar que no beban el agua de zarzaparrilla" 83. La escorzonera (salsifí negro, tarinetes) está considerada como un contraveneno para la mordedura de animales ponzoñosos, razón por la cual en castellano se le llama hierba contra escuerzo ${ }^{84}$. Se toma para el reúma, gota, hipertensión, y contra el estreñimiento: "En enviarme escorzonera, y casi no lo he comido (se refiere a un dulce que han regalado al convento), que me ha quedado terrible hastío de cosas dulces" 85 : este rechazo puede ser indicio de diabetes tipo II. Finalmente, hay una alusión a los escaramojos (rosa canina) tomados en infusión: "Dicen que es bueno para eso de la orina (posiblemente una cistitis), cogidos unos escaramojos cuando están maduros y secos y hechos polvo, y tomar cantidad de medio real a las mañanas. Pregúntelo a un médico" $"$.

También hace referencia al agua de la ciudad de Loja (Granada), famosa por la abundancia de este líquido que brotaba de sus numerosos manantiales en fuentes centenarias, siendo una de las más emblemáticas la fuente santa por sus propiedades curativas para las enfermedades de los ojos, la piel, y las calenturas; era famosa desde tiempos de los árabes, y frecuentada por muchas gentes que hablaba de su poder sanador. Teresa le pregunta a María de San José, si el agua de Loja sería un buen remedio para la calentura de la priora de Malagón -Brianda de San José- y especialmente si aprovecha traída desde tan lejos ${ }^{87}$. A finales de 1577 escribirá a la priora de Sevilla, "Ahora en el agua tengo esperanza de Loja. Ya le he escrito a nuestro padre si se determina. Hare que envíen por ello" 88 .

El jarabe es un medicamento líquido, espeso, y dulce. Comúnmente se dice de la bebida dulce que se trae de la botica para el enfermo, y el dar estos "xaraves" se

82 Cta 117.20: María de San José. Toledo, 7-9-1576.

83 Cta 137.4: María Bautista. Toledo, 31-10-1576.

84 COVARRUBIAS, op.cit. (nota 8), p.366v.

85 Cta 68.3: María Bautista. Segovia, junio 1574.

86 Cta 333.17: María de San José. Segovia, 4-7-1580.

87 Cta 172.3: María de San José. Toledo, 9-1-1577.

88 Cta 177.10. María de San José. Toledo, 26-1-1577. 
llama xaropar ${ }^{89}$ : "Ya estoy casi buena, que el jarabe que escribo a nuestro padre (Domingo Báñez) me ha quitado aquel tormento de melancolía, aun creo la calentura del todo" "90; "Buena estoy, aunque no lo he estado mucho. Este jarabe me da la vida" aunque nunca dice cuáles son los componentes de tan eficaz remedio.

Pastillas o píldoras (del latín pílula que significa pelotilla) son pelotillas medicinales y purgativas que se toman por la boca y los boticarios suelen dorarlas para disimular el amargo del acíbar que llevan dentro ${ }^{92}$. Se trata de medicinas de preparación artesanal en las que se mezclan en un mortero los ingredientes activos con excipientes como jarabes de glucosa en una pasta a la que se le da la forma de cilindro delgado. Luego se secciona o divide en porciones individuales de igual tamaño en forma de pequeñas esferas, y se cubren con un barniz azucarado para hacerlos más agradables a la ingestión:

Harto mijor estoy, que he tomado unas píldoras, creo que me hizo daño comenzar a ayunar en la cuaresma"93; Esa memorias que va ahí de píldoras están loadas de muchos médicos y ordenómelas uno muy grande. Entiendo la harán gran provecho usar, aunque no sea sino de quince en quince días una, que me han hecho gran provecho ${ }^{94}$.

La purga es un preparado que ayuda a eliminar sustancias tóxicas o desechos del organismo: puede ser una sencilla infusión de poleo o manzanilla que mejora las molestias del estómago y reduce la hinchazón estomacal, previniendo gases y facilitando la digestión. Un vaso de agua tibia es un excelente depurador para eliminar toxinas, al tiempo que estimula el tránsito intestinal; se puede añadir limón u orégano bien colado. Puede ser también una mezcla de laxantes tales como aceite de ricino, aceite de oliva, agua templada con sal mezclada con diferentes hierbas. Purgar es limpiar, es dar una bebida de ordinario amarga, y si hace provecho se puede llevar en paciencia $^{95}$. Muchas purgas se elaboraban con ruibarbo: planta herbácea de la familia de las poligonáceas con hojas grandes y ásperas, flores amarillas en espiga y fruto seco; su raíz es la que usaba en medicina como purgante. Radix barbara es una raíz con la que los médicos purgan al enfermo ${ }^{96}$ : "La infusión de ruibarbo hizo gran provecho a dos hermanas que tenían esas hinchazones que lo tomaban algunas mañanas. Trátelo con el médico, y si viere es a propósito tómelo" ${ }^{97}$. Las purgas causaban una dilatación anormal del estómago - gastrectasia- con dolores y vómitos, y para ello eran muy adecuadas las nueces: "Estos días trayo un relajamiento de estómago que vinieron bien las nueces [...] coma las que allá quedan (se refiere al Carmelo de Valladolid)"98.

\footnotetext{
89 COVARRUBIAS, op.cit. (nota 8), p.77v.

90 Cta 63.2: María Bautista. Segovia, 14-5-1574.

91 Cta 102.9: María Bautista. Sevilla, 29-4-1576.

92 COVARRUBIAS, op.cit. (nota 8), p.588.

93 Cta 183.3: Lorenzo Cepeda. Toledo, 27 y 28-2-1577.

94 Cta 396.6: María de San José. Ávila, 8-11-1581.

95 COVARRUBIAS, op.cit. (nota 8), p.600 v.

96 Ibídem, p.16.

97 Cta 348.2: María de San José. Valladolid, 27-12-1580.

98 Cta 70.4: María Bautista. Segovia, 16-7-1574.
} 
La alhucema (lavanda, árnica de monte, barbay, espígol, madresalva) es un antiséptico y un antiespasmódico que puede ingerirse en infusión o aplicarse en la piel. Se recomendaba para infecciones de la piel y en heridas cutáneas. Si se consume como infusión palía los espasmos digestivos, aunque puede provocar gastritis, nauseas, y vómitos. También se utilizaba mezclada con sahumerios o plantas aromáticas. Otro nombre de la alhucema es el espliego y el nardo por la similitud con el aspecto y el olor del trigo y el nardo"99: "Mire no sea ojo, que suele acaecer en sangres livianas. El remedio eran unos sahumerios con erbatum y culantro (cilantro), y cáscaras de huevo $\mathrm{y}$ un poco de aceite y poquito de romero y un poco de alhucema, con esto se quitaban las calenturas" 100 .

Por vía tópica se aplicaban los ungüentos o pomadas, que eran formas farmacéuticas derivadas de la utilización de grasas o sustancias de propiedades similares para aplicación de principios activos en la piel. Su diferencia fundamental con las cremas es la ausencia de agua en su composición. También se denominan untura, unción o unto, por ser una sustancia pastosa que se unta en las heridas con fines curativos ${ }^{101}$. Por el contrario, el bálsamo es líquido y suele hacerse con aceite de oliva mezclado con plantas aromáticas y narcóticas, que se aplica como remedio en las heridas y llagas. En el siglo XVI se trae de las islas occidentales y posee una gran fragancia ${ }^{102}$. Teresa de Jesús recomienda este tipo de remedios para algunas opilaciones: "Yo le digo que me da gran pena esta su calentura [...] Mírese si es de algunas opilaciones, y hágase algo, no se la deje arraigar $[. .$.$] digo que algunas unturas o cosas para templar ese calor, que no lo dejen$ de decir al médico. Ella se suele sangrar cada año, me parece, quizá le haría provecho como dice la subpriora (es Brianda de San José)" ${ }^{103}$; en este caso es posible que se trate de una amenorrea o supresión del flujo menstrual, al aludir a "ese calor" -sofocos- propio de la menarquía: se trata de un enrojecimiento de aparición brusca de la piel en la zona del tórax alto, cuello y cabeza, que se acompaña de una intensa sensación de calor corporal intenso y finaliza en ocasiones con una sudoración profusa, cuya duración va desde unos pocos segundos a varios minutos y raramente hasta una hora. Las opilaciones, según Covarrubias, son también propias de mujeres que no hacen ejercicio, y en este sentido la clausura de las monjas no favorecía en absoluto el movimiento ${ }^{104}$. A propósito de las opilaciones, es interesante detenerse en una costumbre que tenían las nobles y las monjas de comer barro, normalmente dando pequeños mordisquitos a búcaros portugueses realizados en Estremoz, extremeños de Salvatierra de los Barros, o novohispanos traídos de Tonalá, aunque también existían pastillas realizadas con azúcar y ámbar. La ingesta de barro generaba un trastorno llamado opilación, una especie de clorosis o anemia, que producía varios efectos: opilaba o tapaba ciertos conductos, sirviendo como forma de cortar hemorragias, en especial menstruaciones abundantes, a la vez que daba una extrema palidez al rostro como reflejo al efecto biliar que producía en el hígado, porque lucir la piel blanca era signo de verdadera belleza.

\footnotetext{
99 COVARRUBIAS, op.cit. (nota 8), p.48.

100 Cta 158.1: María de San José. Toledo, 13-12-1576.

101 Ibidem, p.60.

102 Ibidem, p.118.

103 Cta 144.3: María de San José. Toledo, 11-11-1576.

104 COVARRUBIAS, op. cit. (nota 8), p.569.
} 
Uno de los remedios quirúrgicos más empleados en la España moderna fueron las sangrías, realizadas por médicos, sangradores, y cirujanos. Este sistema estaba destinado a la evacuación de una cierta cantidad de sangre, para reducir la presión sanguínea. Es general cuando la sustracción se realiza en una vena o en una arteria; y local cuando la sangre procede de los capilares, mediante la aplicación de sanguijuelas o ventosas escarificadas en los brazos, cuello, ingles y tobillos, también se puede hacer por un corte en las venas (flebotomía). La ventosa es un vaso de vidrio en forma de campana, que se aplica sobre una parte del tejido, enrareciendo el aire en su interior al quemar estopa o cáñamo; la ventosa escarificada se aplica sobre una superficie sajada, mientras que la ventosa sajada que se aplica sobre una parte íntegra. Según Covarrubias, sajar es dar unas cuchilladitas muy sutiles sobre las ventosas que llaman sajadas ${ }^{105}$. La práctica continuada de sangrar provocaba anemias ferropénicas agravadas por la mala alimentación:

El dolor que tenía cuando vuestra señoría estaba en Malagón me creció de suerte, que cuando llegué a Toledo me tuvieron que sangrar dos veces, luego no me podía menear en la cama según tenía el dolor de espalda hasta el cerebro, y otro día purgada, y ansíme he detenido ocho días aquí, y me parto bien desflaquecida, porque me sacaron mucha sangre ${ }^{106}$; Que me tienen las sangrías flaca y no está la cabeza para más ${ }^{107}$; No dejó Su Majestad de cumplirle este deseo, que en estos ocho años la sangraron más de quinientas veces, sin tantas ventosas sajadas, que tiene el cuerpo de suerte que lo da a entender. Algunas le echaban sal en ellas, que dijo un médico era bueno para sacar la ponzoña de un dolor de costado, que éstos tuvo más de veinte veces. Lo que es más de maravillar, que así como le decían un remedio de éstos el médico, estaba con gran deseo de que viniese la hora en que le habían de ejecutar, sin ningún temor, y ella animaba los médicos para los cauterios, que fueron muchos, por el zaratán y otras ocasiones que hubo para dárselos ${ }^{108}$; Creo que me tornarán a sangrar... porque no parezca era todo por estar en la Encarnación; verdad es que de allí vino hecho este daño... quizá en este lugar me iría mejor (Alba), y aun aquí no es hasta ahora tan recio el dolor, con mucha parte, como allá ${ }^{109}$.

\section{CUIDADOS PREVENTIVOS}

Aparte de los remedios descritos, Teresa insistía en la importancia de la higiene y la limpieza, por ello una de sus prioridades fue el construir Carmelos con disponibilidad de agua, bien con pozos, o con posibilidades de hacer una conducción adecuada, que además pudiera regar convenientemente la huerta. En la fundación de Duruelo, la primera que se hizo para los carmelitas descalzos de San Juan de la Cruz al frente de Teresa, se cuenta que:

\footnotetext{
105 COVARRUBIAS, op. cit. (nota 8), p.600 v.

106 Cta 8.3: Luisa de la Cerda. Toledo, 27-5-1568.

107 Cta 28.4: Diego Ortíz. Toledo, fin de agosto 1570.

108 F 22.16. Está narrando las enfermedades de Catalina Godínez en el Carmelo de Beas.

109 Cta 56.2: Juana de Ahumada. Salamanca, 14-11-1573.
} 
Estando un día después de cenar el padre fray Antonio, que era prior, en la claustra con sus frailes hablando de la necesidad de agua que tenían, levantóse el prior y tomó un bordón que traía en las manos e hizo en una parte de él la señal de la cruz, a lo que me parece, aunque no me acuerdo bien si hizo cruz; mas, en fin, señaló con el palo y dijo: "ahora, cavad aquí". A muy poco que cavaron, salió tanta agua, que aun para limpiarle es dificultoso de agotar; y agua de beber muy bueno, que toda la obra han gastado de allí, y nunca -como digo- se agota. Después que cercaron una huerta, han procurado tener agua en ella y hecho noria y gastado harto. Hasta ahora, cosa que sea nada, no la han podido hallar ${ }^{110}$.

En el convento de carmelitas descalzos de Granada, fray Juan construyó una noria, una auténtica obra de ingeniería, para conducir las aguas del Darro hasta el edificio, y de paso regar la huerta. Enormemente paradigmática fue la situación de la Encarnación de Ávila, donde el suministro de agua resultaba vital para la subsistencia de una comunidad de clausura. Así lo vio la fundadora Beatriz Guiera, quien al escoger un solar para levantar el cenobio, se inclinó por los terrenos de Fuentes Claras, extramuros de la ciudad, una zona llena de arroyuelos y pequeños manantiales con sus pozos. No hace ahora mismo al caso, pero desde los inicios del monasterio se entabló una auténtica batalla por el agua con los vecinos de la zona, porque las monjas se las ingeniaban para construir cauces que llevaran el líquido directamente al convento, y evitarse salir con los cántaros por cuestiones de clausura ${ }^{111}$.

Teresa también alertaba del exceso de penitencias corporales, que podían producir daños serios en la salud, yendo en contra de una ascesis correctamente comprendida: "En cuaresma se pondrá un día a la semana el cilicio, a condición de que si viere le hace mal se lo quite, que como es tan sanguino témole mucho"112; "Si ese cilicio llegare a toda la cintura, ponga un pañico de lienzo al estómago, que es muy dañoso, y mire que si sintiere mal en los reñones (riñones), que ni eso ni la disciplina no lo tome" 113 . Tampoco gustaba de ayunos muy severos, porque hay que mirar por la salud y regalarse a una misma, y en este sentido recomendaba dormir las horas pertinentes, porque un sueño adecuado prevenía de muchas indisposiciones.

Porque no sería bien si una persona flaca y enferma se pusiese en muchos ayunos y penitencias ásperas, yéndose a un desierto adonde ni pudiese dormir ni tuviese qué comer, o casas semejantes. Mas pensar que nos podemos esforzar con el favor de Dios a tener un gran desprecio de mundo, un no estimar honra, un no estar atado a la hacienda; que tenemos unos corazones tan apretados, que parece nos ha de faltar la tierra en queriéndonos descuidar un poco del cuerpo y dar al espíritu; luego parece ayuda al recogimiento tener muy bien lo que es menester, porque los cuidados inquietan a la oración ${ }^{114}$.

\footnotetext{
$110 \mathrm{~F} 14.5$.

111 GONZÁLEZ Y GONZÁLEZ, N.: La ciudad de las carmelitas en tiempo de doña Teresa de Ahumada, Diputación Provincial de Ávila, Institución Gran Duque de Alba, 2011.

112 Cta 179.5: Lorenzo Cepeda. Toledo, 10-2-1577.

113 Cta 183.11: Lorenzo Cepeda. 27 y 28-2-1577.

114 V 13.4.
} 
Conviene destacar que las monjas no padecían pestes, a pesar de las epidemias que azotaban la península con cierta periodicidad, debido a unas condiciones higiénicas y sanitarias mejores que las del resto de la población, auspiciadas, aparte del uso del agua, por el aislamiento que producía la clausura -nos referimos a la construcción del habitáculo, los muros de los conventos, las puertas y rejas aislantes, y a la prohibición, tanto de entrar gente como de salir monjas- al impedir la penetración de los contagios. También influía de forma notable la dieta alimenticia, que, en conjunto, podía considerarse altamente favorable para una vida sana, y desde este punto de vista mejor que la de los frailes: los productos hortícolas -verduras, leguminosas y frutas- aportaban vitamina $\mathrm{A}$, vitamina $\mathrm{C}$, ácido fólico, vitamina B12 y oligoelementos; tomaban abundante pan -sin especificar si blanco o negro-; según las noticias que ofrece la fundadora, disponían de algunas aves, huevos, pescado en salazón; no abundaba el dulce, cuestión especialmente beneficiosa para el colesterol; el único problema era que carecían de leche con la consiguiente falta de calcio que producía enfermedades óseas como dolores y roturas. El posible déficit alimenticio no sobreviene porque sea una dieta pobre, sino por la escasez de alimentos causada por las penurias económicas, provocando el descenso de las defensas ${ }^{115}$ :

La esterilidad de este pueblo en cosas de pescado, que es, lastima a estas hermanas; y ansí me he holgado con estos besugos. Creo pudieran venir sin pan, según hace el tiempo. Si acertare haberlos cuando venga Serna, o algunas sardinas frescas, de vuestra merced a la subpriora con que nos las envíe, que lo ha enviado muy bien [...] 34 . Terrible lugar es este para no comer carne, que aun un huevo fresco jamás hay ${ }^{116}$.

La vida carmelitana es dura en cuanto que solo hay dos únicas ingestas: comida entre diez y once de la mañana, y colación sobre las seis se la tarde, además de los tiempos establecidos de ayuno; "Hase de ayunar desde la exaltación de la Santa Cruz (14 de septiembre) hasta la pascua de Resurrección, excepto los domingos [...] No se ha de comer carne perpetuamente sino fuere con necesidad y cuando lo mande la regla" ${ }^{117}$; "Ninguna hermana hable en si se da poco o mucho de comer, bien u mal guisado. Tenga la priora y provisora cuidado de que se conforme a lo que hubiere" 118 ; "En la hora de comer no puede haber concierto...en verano se tañerá a comer a las 10 ...fuera de comer y cenar ninguna hermana coma y beba sin licencia" ${ }^{119}$. En principio la carne es un alimento excluido de la dieta, aunque se hicieron muchos ajustes desde la Edad Media; se decía que la carne de cuadrúpedo impedía enfrentarse eficazmente a las pasiones, pero sin embargo sí se podían ingerir aves fuera de los tiempos

115 Teresa nombra muchos alimentos en su obra, al tiempo que describe profusamente la carestía de ellos con términos como hambre, hambriento, y hambrería. Abadejo (bacalao en salazón), aceite, aloja (bebida a base de agua, miel, canela, y pimienta), atún, aves, azúcar, besugo, brinquiño (dulce portugués), carnero, cocos, cogombro (pepino), confite (pasta de azúcar en forma de bola), empanada, fruta (melón, manzana, naranja), gallina, gallo, harina, huevos, lechugas, licor, limón, manteca, mantequilla, membrillo, mermelada, miel, nuez, obleas (hoja delgada de agua y harina), olivas, palomas, palominos, pastel, patata, rábanos, sábalo (pescado azul semejante al chicharro), sardina, seroja, torta, trigo, trucha, verdura.

116 Cta 168. 33 y 34: Lorenzo Cepeda. Toledo, 2-1-1577.

117 C 3.1 .

118 C 6.2 .

119 C 6.4 . 
de ayuno: "Ya escribí al señor don Francisco el cuidado que vuestra merced tiene y cuán buenas vinieron las aves" ${ }^{120}$. Para las enfermas recomienda carne: "Holgádome he que mande nuestro padre (Jerónimo Gracián) que coman carne las dos de la mucha oración" 121; "El padre fray Bartolomé como es enfermo no puede dejar de comer carne" ${ }^{122}$, así como naranjas: "Yo no había enviado a la priora de Malagón de los que me envió mi hermano (se refiere a confites), por la mucha calentura que tiene, que la matara [...] más de otras cosas es muy bien, tal como naranjas dulces"123.

Aparte de evitar las pestes, las monjas tampoco padecían los riesgos de los embarazos, los posibles abortos, los partos, y los puerperios, que fueron la causa de la mortalidad femenina del antiguo régimen, haciendo que muchas mujeres, y especialmente las reinas, no llegaran a alcanzar la cuarentena. Por tanto, el aislamiento y las condiciones higiénicas, sanitarias y alimenticias, unidas a la no existencia de pestes y embarazos, hacía que las monjas fuesen personas longevas, puesto que muchas llegaban a los sesenta y setenta años -Teresa de Jesús murió con 67 años-, convirtiendo el estado religioso femenino en una posible liberación de las condiciones materiales de vida de los siglos XVI y XVII, y, especialmente, de aquellas que limitaban y constreñían la existencia de las mujeres.

Todas las reglas monásticas se ocupan con especial cuidado de los enfermos. Las constituciones teresianas dedican el capítulo 7 a esta cuestión:

Las enfermas sean curadas con todo amor y regalo y piedad [...] en las enfermedades no se desconsuelen, que a eso han de venir determinadas [...] en esto ponga mucho cuidado la madre priora, que antes falte lo necesario a las sanas que algunas piadades a las enfermas. Sean visitadas y consoladas de las hermanas. Póngase enfermera que tenga para este oficio habilidad y caridad [...] sean las enfermas obedientes a la enfermera [...] tengan lienzo y buenas camas, y sean tratadas con limpieza y caridad

Las pautas de Teresa siguen fielmente la consideración que tradicionalmente han tenido las órdenes religiosas hacia los enfermos. La enfermería siempre estaba situada en uno de los mejores lugares de la casa desde el punto de vista de la orientación: una zona caliente en invierno y fresca en verano; y desde el punto de vista de las condiciones adecuadas para la sanación: ventanas y galerías comunicadas con el jardín o la huerta, para facilitar aire puro y paseos. En la Encarnación de Ávila se ubicaba en la planta baja de la crujía este con vistas al campo y a la ciudad ${ }^{124}$. Es frecuente encontrar en los memoriales conventuales recomendaciones acerca de la conveniencia de que se encarguen de la enfermería las personas más capacitadas para ejercer cuidados médicos, por eso el dispensario estaba siempre en manos de una o dos enfermeras. Teresa insistía a las enfermas que obedecieran siempre a la enfermera, así como a los consejos del médico, cuyo diagnóstico era atendido con precisión. La especialización de esta dependencia no excluía el que las reglas monásticas acentuaran de manera

120 Cta 46: Martín Dávila Maldonado. Ávila, 1-2-1572.

121 Cta 237.13: María de San José. Ávila, 4-6-1578.

122 Cta 355.2: Jerónimo Gracián. Palencia, 17-2-1581.

123 Cta 177.9: María de San José. Toledo, 26-1-1577.

124 GONZÁLEZ Y GONZÁLEZ, N, op.cit. (nota103), pp.233-246. 
especial el trato preferente hacia los enfermos por parte de las preladas. La enfermera por antonomasia fue Ana de San Bartolomé, además de secretaria y cocinera de la fundadora: las palabras de Ana en su Autobiografía describen no solo su labor como enfermera de la fundadora, sino cómo debe de ser el trabajo de la enfermería:

Yo, de que se dormía, me arrimaba pasito a par de su cama sentada, y cuando me llamaba, hacía que venía de nuestra cama, y decíame la santa: “¿cómo hija vienes tan presto?" Otras veces la dejaba durmiendo y me iba a lavar sus paños, que como estaba enferma tenía yo consuelo de darla limpio. Era muy agradable a ella la limpieza. Yo me estaba muchas noches sin dormir, y no me hacía falta el sueño por darla contento, yo le tenía muy grande hasta su muerte ${ }^{125}$

Otras causas que influyeron considerablemente en la salud de las monjas fue la ubicación de los conventos ${ }^{126}$. La Encarnación era un edificio amplio construido en 1515, pero la entrada constante de monjas -180 se llegaron a contabilizar en tiempos de la Santa- desembocó en la pobreza y la penuria, porque la hacienda no cubría ni tan siquiera las necesidades primarias. Las cercas eran de tapial, y las cubiertas de la iglesia y del coro eran a teja vana, de forma que en invierno se colaba la nieve sobre los breviarios, y en verano el sol. Las celdas variaban de acuerdo a la dote que traía cada monja: unas dormían en el dormitorio comunal, y otras disponían de una habitación con su cocina y su pequeña alcoba. La nota característica de estos habitáculos era la falta de luz, higiene, ventilación, y calor, como consecuencia de una anarquía arquitectónica que iba ampliando el edificio conforme entraban nuevas monjas. La celda de Teresa estaba en la crujía oriental de la planta baja, junto a la escalera del capítulo, y debajo de la enfermería: tenía dos aposentos de diferente altura: en el bajo estaba el oratorio con un hueco para imágenes, y en el alto el catre con el jergón de paja y la sábana de estameña. La ventana se abría hacia levante (muchas celdas daban al interior), y por eso tuvo la suerte de poder contemplar en la lejanía las torres de la catedral y de la iglesia de San Vicente.

En San José Âvila estaban sujetas al aire y a la nieve, de forma que con la mano se podía alcanzar el techo, que por partes estaba roto, y ponían lienzos para las inclemencias del tiempo. Las celdas eran reducidas, y las monjas dormían en un catre con jergón, y se sentaban en el suelo para escribir. En San José se pasó mucha hambre: en verano tomaban una ensalada de cogombros y un poco que queso; Julián de Ávila, capellán perpetuo, afirmó que jamás se comía carne, además de ayunar ocho meses al año. Los tejidos de las ropas no favorecían el mantenimiento adecuado de la piel: hábito y capa de jerga, alpargatas de esparto, toca y almohada, sábanas de estameña, mantas de sayal, jergón de paja sin almohada, jamás lienzo en las camisas interiores, siempre de estameña.

Al llegar a la casa de Medina del Campo, se encontró con un patio de paredes caídas. En Malagón empezaron viviendo en una casa en el centro del pueblo con mucho ruido y muy insalubre, y por ello exigió a la patrona, Luisa de la Cerda, otra ubica-

125 URKIZA, J., op,cit. (n.74), p.350.

126 SÁNCHEZ HERNÁNDEZ, Ma . L.: "Vida cotidiana en los carmelos fundados por Santa Teresa", $X X X I$ Ruta cicloturística del románico internacional, Pontevedra, 2013, pp.57-64. 
ción; la misma Teresa buscó solar en un olivar cercano para construir el convento con planos encargados a Nicolás de Vergara y dirigido personalmente por ella, pero no pudieron mudarse hasta 1576. En el Carmelo de Toledo dice que, "estuvimos algunos días con los jergones y la manta, sin más ropa, y aun aquel día ni una seroja de leña no teníamos para asar una sardina [...] nos pusieron en la iglesia un hacecito de leña, con que nos remediamos. A las noches se pasaba algún frío, que le hacía; aunque con la manta y las capas de sayal que traemos encima nos abrigábamos, que muchas veces nos aprovechan" ${ }^{127}$. El convento de Valladolid estaba al lado del Pisuerga, y casi todas las monjas padecieron paludismo por la continua humedad: "Estuvimos allí poco, porque caímos casi todas muy malas" ${ }^{28}$; en la nueva casa tuvieron corral y corralito con suelo y cobertizo, con jardín atajado y tapiado: extramuros de la villa. La primera casa de Salamanca era muy grande y desbaratada y con muchos desvanes: "Estuvo el monasterio en esta casa cerca de tres años, [...] Sentí harto ver lo que estas hermanas padecieron aquí, aunque no de falta de mantenimiento (que de esto yo tenía cuidado desde donde estaba, porque estaba muy desviada la casa para las limosnas), sino de poca salud, porque era húmeda y muy fría, que como era tan grande, no se podía reparar" ${ }^{129}$. En Sevilla estuvieron al principio en un edificio pequeño y húmedo con media docena de cañizos y camas traídos del convento de los Remedios; dos o tres colchoncillos con pulgas y chinches; sin sábanas, ni mantas, ni almohadas. La comida eran manzanas y pan, a veces guisadas o en ensalada: "El buen Garciálvarez aderezó nuestra claustra $[\ldots]$ tenía una fuente, que el agua era de azahar, sin procurarlo nosotras ni aun quererlo, aunque después mucha devoción nos hizo" "130; se acomodaron en dos cuartos con cocina y una pequeña tribuna para oír misa, que justo quedaba debajo del tejado: estaba lleno de insectos y ruidos. Posteriormente, se mudaron y compraron una buena casa cerca del río y de la iglesia.

\section{CONSIDERACIÓN FINAL}

Termino con dos textos de Teresa en los que hace una reflexión acerca de la enfermedad y el dolor $-\mathrm{y}$ en definitiva de la muerte- como realidades imprescindibles de comprender en el marco de la condición humana tomada en su totalidad -vida-muerte; fortaleza-fragilidad; dolor-bienestar; tristeza-enfermedad- y, especialmente, como instancias que trasciende la propia existencia, desde el instante en que no están controladas por mano humana. En este sentido, Teresa traza una espléndida teología del dolor, en la que no se trata de adoptar una actitud dolorista de resignada aceptación ante los contratiempos biológicos, ni mucho menos instalarse en un lamento egoísta que daña a la enferma y a los de su entorno. Por un lado, se trata de aprender a ejercer la fortaleza mirando a los más desvalidos, que no tienen cuidados ni acompañamiento, conviviendo y relativizando los males cotidianos que no son graves. Por el otro,

127 F 15.13

128 F 10.6.

129 F 19.3 у 6.

130 F 25.12. 
propone un ars moriendi -aprender a morir- ante enfermedades muy graves -dolores muy recios- que descomponen el exterior -el cuerpo- y el interior de las personas.

Cosa imperfecta me parece, hermanas mías, este quejarnos siempre con livianos males; si podéis sufrirlo, no lo hagáis. Cuando es grave el mal, él mismo se queja; es otro quejido y luego se parece. Mirad que sois pocas, y si una tiene esta costumbre es para traer fatigadas a todas, si os tenéis amor y hay caridad; sino que la que estuviere de mal que sea de veras, lo diga y tome lo necesario; que si perdéis el amor propio, sentiréis tanto cualquier regalo, que no hayáis miedo le toméis sin necesidad ni os quejéis $\sin$ causa $^{131}[\ldots]$ Adonde hay caridad y tan pocas, que nunca falte el cuidado de curaros. Mas unas flaquezas y malecillos de mujeres, olvidaos de quejarlas, que algunas veces pone el demonio imaginación de esos dolores; quítanse y pónense. Si no se pierde la costumbre de decirlo y quejaros de todo si no fuere a Dios, nunca acabaréis $^{132}[\ldots]$ 11.3. Acordaos qué de pobres enfermos habrá que no tengan a quién se quejar [...] Acordaos también de muchas casadas; -yo sé que las hay- y personas de suerte, que con graves males, por no dar enfado a sus maridos, no se osan quejar, y con graves trabajos. [...] que no venimos aquí a ser más regaladas que ellas ${ }^{133}$ En todo esto que he dicho, no trato de males recios, cuando hay calentura mucha, aunque pido haya moderación y sufrimiento siempre, sino unos malecillos que se pueden pasar en pie. Mas ¿qué fuera si éste se hubiera de ver fuera de esta casa?, ¿qué dijeran todas las monjas de mí? Y ¡qué de buena gana, si alguna se enmendara, lo sufriera yo! Porque por una que haya de esta suerte, viene la cosa a términos que, por la mayor parte, no creen a ninguna, por graves males que tenga ${ }^{134}$.

También suele dar el Señor enfermedades grandísimas. Este es muy mayor trabajo, en especial cuando son dolores agudos, que en parte, si ellos son recios, me parece el mayor que hay en la tierra digo exterior aunque entren cuantos quisieren; si es de los muy recios dolores, digo, porque descompone lo interior y exterior de manera que aprieta un alma que no sabe qué hacer de sí; y de muy buena gana tomaría cualquier martirio de presto, que estos dolores; aunque en grandísimo extremo no duran tanto, que en fin no da Dios más de lo que se puede sufrir, y da Su Majestad primero la paciencia; mas de otros grandes en lo ordinario y enfermedades de muchas maneras ${ }^{135}$.

\footnotetext{
131 Cp 11.1.

132 Cp 11.1.

133 Cp 11.3.

134 Cp 11.4.

135 M 6.6.
} 